\title{
Strategi City Branding Kota Surabaya Sparkling Surabaya dalam Meningkatkan Kunjungan Wisatawan
}

\author{
Surabaya City Branding Strategy Sparkling Surabaya in \\ Increasing Tourist Visits
}

\author{
Caisar Pieter Vega Arwanto, Bagus Setyawan Nugraha \& Agus Widiyarta* \\ Ilmu Administrasi Publik, Fakultas Ilmu Sosial dan Ilmu Politik, \\ Universitas Pembangunan Nasional “Veteran” Jawa Timur, Indonesia
}

Diterima: 31 Maret 2020; Disetujui: 30 April 2020; Diterbitkan: 01 Juli 2020

\section{Abstrak}

Penelitian yang dilakukan oleh penulis berjudul "Strategi City Branding Kota Surabaya "Sparkling Surabaya" Dalam Meningkatkan Kunjungan Wisatawan". Tujuan dari penelitian ini adalah untuk mengetahui bagaimana strategi city branding Kota Surabaya dalam meningkatkan kunjungan wisatawan. Hal tersebut dibutuhkan karena Kota Surabaya banyak memiliki potensi dalam sektor pariwisata seperti adanya taman-taman yang berada di pusat kota, wisata kuliner, tempat-tempat bersejarah. Penulis menggunakan teori dari Anholt tentang strategi umum dalam pemasaran atau pengembangan kota dan Kotler tentang city branding hexagon untuk mengetahui bagaimana strategi city branding Kota Surabaya dalam meningkatkan kunjungan wisatawan. Jenis penelitian yang digunakan yaitu literature review dimana penelitiannya di dalam perpustakaan dan mengkaji literature yang merupakan sumber data primernya. Pendekatan penelitian menggunakan analisis secara deskriptif kualitatif. Hasil dari penelitian ini pemerintah Kota Surabaya dalam meningkatkan wisatawan, menggunakan strategi pemasaran atau promosi city branding "Sparkling Surabaya" melalui website, akun instagram, Bus SSCT, dan diadakannya event-event atau kegiatan salah satunya Car Free Day. Penelitian ini menyimpulkan bahwa strategi city branding yang digunakan adalah strategi pemasaran atau promosi dan acara, dalam meningkatkan kunjungan wisatawan.

Kata Kunci: City Branding, Strategi, Pariwisata

\section{Abstract}

Research conducted by the author entitled "Surabaya City Branding Strategy" Surabaya Sparkling "In Increasing Tourist Visits". The purpose of this study is to find out how the Surabaya city branding strategy in increasing tourist visits. This is needed because the city of Surabaya has a lot of potential in the tourism sector such as parks in the city center, culinary tours, historic sites. The authors use Anholt's theory of general strategies in marketing or urban development and Kotler's hexagon city branding to find out how Surabaya's city branding strategy is in increasing tourist arrivals. The type of research used is the literature review where the research is in the library and study the literature which is the primary data source. The research approach uses descriptive qualitative analysis. The results of this study the Surabaya city government in increasing tourists, using the marketing strategy or promotion of city branding "Sparkling Surabaya" through the website, Instagram account, SSCT Bus, and holding events or activities one of them Car Free Day. This study concludes that the city branding strategy used is a marketing or promotion and event strategy, in increasing tourist visits.

Keywords: City Branding, Strategy, Tourism

How to Cite: Arwanto, C.P.V, Nugraha, B.S \& Widiyarta, A (2020). Strategi City Branding Kota Surabaya Sparkling Surabaya Dalam Meningkatan Kunjungan Wisatawan. PERSPEKTIF, 9(2): 322-328

\footnotetext{
*Corresponding author:

E-mail: aquswidivarta@yahoo.co.id
}

ISSN 2085-0328 (Print) ISSN 2684-9305(Online) 


\section{PENDAHULUAN}

Negara Indonesia merupakan negara kemaritiman, yang terdiri dari beberapa pulaupulau yang kaya akan potensi wisatanya di tiap daerah-daerahnya. Seperti yang diketahui, banyak tempat wisata yang memiliki keindahan alam dan dapat di kelola dengan baik oleh masyarakat dan pemerintah daerah. Berdasarkan (Undang - Undang Republik Indonesia No. 9 Tahun 1990 Tentang Kepariwisataan) pasal 1 (5) Pariwisata adalah segala sesuatu yang berhubungan dengan wisata serta usaha-usaha yang terkait di bidangnya. Setiap daerah pasti ingin mengembangkan dan memperkenalkan destinasi-destinasi wisatanya, sehingga dapat dijadikan tempat berkunjung untuk masyarakat lokal maupun wisatawan mancanegara. Pilihan tujuan berwisata merupakan indikator gaya hidup bagi wisatawan yang memilih untuk menghabiskan waktu santai mereka dengan berlibur. Hal tersebut bisa menjadi alasan karena pariwisata adalah sektor bidang yang menjadi andalan bagi setiap daerah yang memiliki potensi.

Seiring dengan berkembangnya otonomi daerah, setiap daerah berhak bebas mengatur daerahnya sendiri, termasuk dalam bidang pariwisata yang mampu membuat kota atau daerah tersebut diminati oleh para wisatawan, sehingga kota atau daerah tersebut mendapatkan pendapatan dari sektor pariwisata. Dalam perkembangan zaman di era globalisasi dan perkembangan teknologi saat ini, dapat dijadikan suatu strategi dalam pengenalan sector-sektor pariwisata di daerah tersebut secara efektif dan lebih efisien. Pengenalan budaya, hiburan, tempat destinasi pariwisata, dan tempat-tempat kreativitas yang dibangun oleh masyarakat atau pemerintah, pastinya memerlukan adanya kegiatan pemasaran. Menurut Philip Kotler (1967) dikutip dari (Setiyaningrum, Udaya, \& Effendi, 2015) pemasaran adalah kegiatan menganalisis, mengorganisasi merencanakan dan mengawasi sumber daya, kebijaksanaan, serta kegiatan yang menimpa para pelanggan perusahaan dengan maksud memuaskan kebutuhan dan keinginan para kelompok pelanggan yang terpilih untuk memperoleh laba. Place marketing is closely connected with all aspects of branding in its communicative sense as a process, and the results of linguistic studies of branding phenomenom can promote to solve real economic tasks (Novikova, Mityagina, Gureeva, \& Makhortova, 2018).

Kegiatan pemasaran memerlukan sebuah brand yang melekat pada barang. jasa yang akan dipasarkan. Umumnya brand selalu diaplikasikan kepada suatu produk atau jasa, namun dalam konteks ini, brand diaplikasikan untuk suatu daerah atau kota yang kemudian disebut sebagai city branding. Menurut Wheeler (2009:6) dikutip dari (Hidayat \& Thamrin, 2019) branding merupakan suatu proses teratur yang digunakan untuk membangun kesedaran serta menambah loyalitas konsumen. Menurut Bawanti (2016) dikutip dari (Nawangsari \& Suksmawati, 2019) Branding in the sense of city branding is to give a brand to the city so that it can be easily recognized and can form a city image to market the area both locally and internationally. Menurut Kolb (2006:219) dikutip dari (Wibowo, 2018) Branding memiliki banyak keuntungan, termasuk mengurangi resiko pembelian kosumen, membangun kewaspadaan dengan mengkomunikasi pesan yang konsisten, menyemangati untuk mendorong konsumen datang kembali, menumbuhkan keloyalan dan asosiasi dengan kota dengan identitas unik. Menurut Mihardja (2019) dikutip dari (Romli \& Romli, 2020) city branding dapat di definisikan sebagai jaringan asosiasi dalam benak konsumen, berdasarkan ekspresi visual, verbal dan perilaku dari suatu tempat yang diwujudkan melalui tujuan, komunikasi, nilai-nilai, dan budaya umum para pemangku kepetingan. Menurut Yulianti (2014) dikutip dari (Hilman \& Megantari, 2018) kegiatan city branding, dapat dilihat dari berbagai image yang akan dibuat di sebuah wilayah khususnya, yang berkaitan dengan pembangunan wisata. City branding atau branding kota merupakan perangkat baru dalam pembangunan wilayah untuk meningkatkan daya saing menghadapi kompetisi global (Lauwrentius, Fianto, \& Yosep, 2015). Menurut Servin (2014) dikutip dari (Hambalah, 2017) city branding adalah kumpulan asosiasi-asosiasi yang terdapat dibenak seseorang mengenai 
suatu kota atau yang dipersepsikan mengenai kota tersebut. Menurut Prasetyo (2012) dikutip dari (Pantow \& Fista, 2018) City branding adalah proses atau usaha membentuk brand dari suatu kota untuk mempermudah pemilik kota tersebut memperkenalkan kotanya kepada target pasar (investor, tourist, talent, event) dengan menggunakan kalimat positioning, slogan, icon, eksibisi dan berbagai media lainnya. City branding is a relatively new concept and involves the recognition of a given city at various levels as well as the way in which political actors work on those factors (Ferreira \& Dionísio, 2019).

Surabaya merupakan sebuah kota atau daerah yang terletak di Jawa Timur, dan sekaligus menjadi Ibu Kota Provinsi Jawa Timur. Kota Surabaya banyak memiliki potensi dalam sektor pariwisata seperti adanya pantai, tamantaman yang berada di pusat kota, wisata kuliner, tempat-tempat bersejarah, penampilan budayabudaya khas Kota Surabaya dan masih banyak lagi. Kota Surabaya sudah memiliki city branding yang bertemakan "Sparkling Surabaya" sebagai upaya untuk memperkenalkan potensi wisata yang ada di Surabaya.

Akan tetapi banyak masyarakat luar Kota Surabaya dan beberapa masyarakat Kota Surabaya masih belum mengetahui atau mengenal city branding, bahkan sektor pariwisata di daerah Kota Surabaya. Hal tersebut bisa dilihat dari kesimpulan yang ada di dalam penelitian terdahulu (Ramadhan, Suharyono, \& Kumadji, 2015) yang berjudul "Pengaruh City Branding Terhadap Minat Berkunjung Serta Dampaknya Pada Keputusan Berkunjung (Survey pada Wisatawan Kota Surabaya 2015)" yang menyatakan bahwa City branding berpengaruh tidak signifikan terhadap keputusan berkunjung dilihat dari koefisien jalur $\left({ }^{\beta}\right)$ sebesar 0,091 hal tersebut dikarenakan bahwa city branding tidak langsung menjadi pertimbangan wisatawan untuk memutuskan berkunjung, dibutuhkan stimulus untuk menarik minat wisatawan yang dapat dilakukan melalui media promosi.

Dengan demikian berdasarkan fenomena di atas, untuk mengetahui bagaimana Strategi City Branding Kota Surabaya dalam meningkatan Kunjungan Wisatawan. Dalam hal ini penulis menggunakan teori City Branding Hexagon dan Strategi City Branding dalam Pengembangan Kota.

Menurut Anholt (2007) dalam (Intyaswono et al., 2016) terdapat enam aspek dalam pengukuran yaitu presence, potential, place, pulse, people, prerequite.

Menurut Nanang Fattah \& H. Mohammad Ali. (2008) dikutip dari (Arifin, 2017) mendefinisikan strategi sebagai pemikiran secara konseptual, realistis tentang langkahlangkah yang diperlukan untuk mencapai tujuan dan sasaran yang telah ditetapkan.

Terdapat strategi umum yang terbagi menjadi empat, dalam memasarkan atau mendorong agar suatu kota dapat menjadi lebih menarik bagi wisatawan, pengusaha, ataupun investor ke kota atau wilayah tertentu. Menurut Kotler (2002) dikutip dari (Intyaswono et al., 2016) yaitu dengan Pemasaran citra (Image Marketing), Pemasaran atraksi/daya tarik (attraction marketing), Pemasaran prasarana (infrastructure marketing), Pemasaran penduduk (people marketing).

\section{METODE PENELITIAN}

Metode penelitian yang digunakan yaitu kepustakaan (library research) atau literature review. Menurut Kuswana (2011), dikutip dari (Musaddad, Rahayu, Pratama, Supraptiningsih, \& Wahyuni, 2011) literature review merupakan dimana penelitiannya di dalam perpustakaan dan mengkaji literature yang merupakan sumber data primernya. Menurut (Soewadji, 2012) penelitian kepustakaan adalah penelitian yang dilakukan di kepustakaan. Hasil dari penggunaan literatur ini untuk mengindentifikasi definisi, pola, dan model strategi city branding dalam peningkatan kunjungan wisatawan.

Jenis penelitian yang digunakan adalah kualitatif. Penelitian kualitatif digunakan karena memiliki karakteristik yang sesuai dengan topik penelitian. Dalam penelitian kualitatif data yang dihasilkan merupakan data deskriptif yaitu berupa kata-kata tertulis atau lisan dari obyek yang diamati (Himawan, 2018). 


\section{HASIL DAN PEMBAHASAN}

\section{Strategi Pemasaran Dalam Pengembangan Kota}

Kegiatan dari Strategi City Branding kota Surabaya dalam meningkatan kunjungan wisatawan adalah :

Pemasaran citra (image marketing): dalam memasarkan citra Kota Surabaya sebagai kota metropolitan, pemerintah kota Surabaya memiliki sebuah slogan yaitu "Sparkling Surabaya".

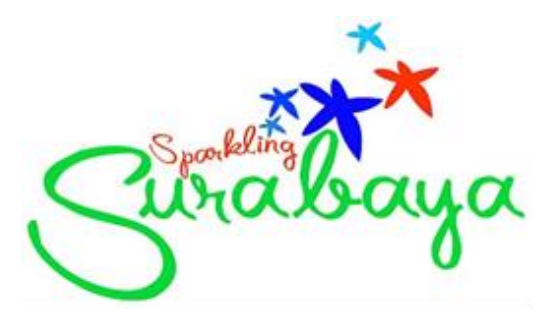

Gambar 1. Sparkling Surabaya

Konsep dan arti dari logo Sparkling Surabaya diambil dari berbagai potensi wisata kota Surabaya yang dilihat dari geografis dan karakter destinasi wisata masing-masing. Tulisan Sparkling Surabaya yang menggunakan warna biru menunjukkan bahwa Surabaya merupakan kota pesisir, sedangkan warna hijau menunjukkan bahwa Surabaya adalah kota yang mengedepankan green and clean. Warna bintang yang ada di atas tulisan Sparkling Surabaya mempunyai arti, warna bintang emas mewakili kawasan Surabaya selatan, warna bintang biru mewakili kawasan Surabaya utara yang dekat dengan laut, bintang warna kuning mewakili kawasan Surabaya timur yang mempunyai pantai dan jembatan suramadu sebagai ikon pariwisatanya, bintang warna orange mewakili kawasan Surabaya barat yang dimana kawasan pusat belanja dan rekreasi dengan standar internasional, dan bintang warna merah mewakili kawasan CBD (Central Business District) atau pusat kawasan bisnis.

Pemasaran Atraksi/daya tarik (attraction marketing): kota Surabaya memiliki banyak sekali atraksi atau keindahan alam, tempattempat bersejarah, taman, bangunan, mal-mal besar, budaya, makanan khas, event-event atau acara, dan lainnya. Salah satu contoh event atau acara adalah parade Surabaya juang 2019, parade Surabaya juang ini diawali dengan sebuah drama/pertunjukan pertempuran antara masyarakat Surabaya melawan tentara sekutu. Diwarnai dengan suara-suara bom dan senjata perang, serasa suasana seperti pertempuran yang sebenarnya. Setelah itu dilanjutkan dengan pawai dari tugu pahlawan sampai ke jalan darmo. Acara tersebut juga banyak mengundang wisatawan.

Pemasaran dan prasarana (insfrastructure marketing): dalam menjalankan kegiatankegiatan City Branding, kota Surabaya juga membangun prasarana sebagai pendukung wisata yang berguna untuk menarik daya tarik wisatawan dan dapat dengan mudah untuk diakses informasi-informasi terkait tentang kota Surabaya. Salah satunya dengan adanya situs Sparkling Surabaya (https://sparkling.surabaya.go.id/en/). Tidak hanya website saja untuk dapat mendukung daya tarik, namun wisatawan dapat menggukan aplikasi instagram untuk mengetahui tentang informasi dan apa saja tempat-tempat wisata di kota Surabaya yaitu dengan melihat akun (@sparklingsurabaya) di instagram.

Pemasaran penduduk (people marketing): pemerintah Kota Surabaya tidak bisa mengandalkan promosi saja, dan aktif dalam menyuarakan kota Surabaya sebagai kota metropolitan, akan tetapi peran dan kerjasama dari masyarakat juga dibutuhkan untuk membuat lingkungan menjadi kondusif atau aman bagi kemajuan pariwisata atau eventevent yang dilaksanakan. Para penduduk kota Surabaya dikenal memiliki keramahan dan membudayakan kebersihan dengan membuang sampah pada tempatnya. Kota Surabaya memiliki sumber daya manusia yang kompeten, dilihat dari banyaknya kegiatan wirausaha (UKM atau UMKM) yang dilakukan masyarakat, dan banyaknya masyarakat yang berkerja di sektor industri. Kota Surabaya memiliki salah satu pahlawan yaitu Sutomo atau biasa dikenal sebagai Bung Tomo, beliau adalah salah satu pemimpin yang menggerakan dan membangkitkan semangat rakyat Surabaya yang disuarakan atau disiarkan melalui radionya dengan penuh semangat kemerdekaan. 


\section{City Branding Hexagon}

Terdapat enam aspek untuk mengetahui apakah city branding memiliki dampak sehingga meningkatkan kunjungan wisatawan, yaitu dengan menggunakan City Branding Hexagon:

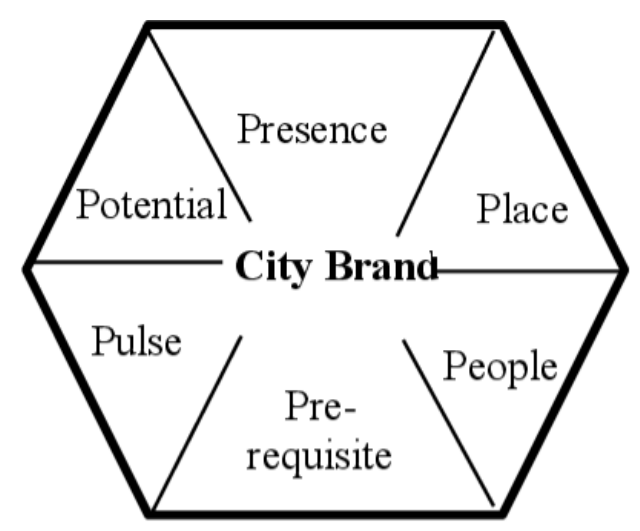

Gambar 2. City Branding Hexagon

Presence: Aspek ini digunakan untuk mengukur city branding dari suatu kota berdasarkan status internasional dari suatu kota. Di kota Surabaya terdapat banyak situs dan bangunan-bangunan peninggalan Belanda atau semasa pemerintahan Hindia Belanda itu masih tersisa hingga menjadi aset dan sebagai kunjungan wisata.

Potential: Aspek ini digunakan untuk mengukur city branding dari suatu kota berdasarkan peluang ekonomi dan pendidikan dalam suatu kota. Dalam segi ekonomi di kota Surabaya terdapat tempat kawasan bisnis atau CBD (Central Business District). Sedangkan dalam segi pendidikan, kota Surabaya memiliki banyak universitas negeri dan universitas swasta, yang dimana memiliki akreditasi yang baik. Untuk sekolah negeri atau swasta yang berada di Surabaya, sudah memiliki fasilitas teknologi yang baik, fasilitas bangunan yang nyaman, fasilitas buku yang menunjang pendidikan, dan lainnya.

Place: Aspek ini digunakan untuk mengukur city branding dari suatu kota berdasarkan persepsi masyarakat tentang aspek fisik dari masing-masing kota dari segi iklim, kebersihan lingkungan dan bagaimana tata ruang kota. Dalam hal ini, kota Surabaya merupakan kota pahlawan, dikarenakan kota Surabaya memiliki banyak sekali sejarah, mulai dari tempat bersejarah dan lainnya. Kota Surabaya adalah kota yang sangat gencar dengan kegiatan green and clean, hal tersebut juga tertera di salah satu warna bintang yang ada di logo city branding, oleh karena itu kota Surabaya memiliki banyak taman-taman, dan lainnya.

Pulse: Aspek ini digunakan untuk mengukur city branding dari suatu kota berdasarkan persepsi bahwa ada hal-hal yang menarik dalam suatu kota, entah itu kegiatan kota atau acara yang mampu mengisi waktu luang atau dapat menarik minat pengunjung. Salah satu kegiatan yang dilakukan pemerintah kota Surabaya adalah dengan adanya Surabaya Shopping \& Culinary Track (SSCT). SSCT merupakan armada bus wisata yang akan membawa para wisatawan untuk berkeliling menikmati berbagai macam obyek wisata di Surabaya dan sekaligus mendapatkan perjalanan yang menyenangkan. Kegiatan Bus SSCT dilakukan pada hari selasa, sabtu, dan minggu pada pukul 09.00 - 14.00 WIB, dengan harga tiket hanya Rp.7500,-.

People: Aspek ini digunakan untuk mengukur city branding dari suatu kota berdasarkan seberapa ramah penduduk setempat, komunitas-komunitas apa saja yang ada di lingkungan masyarakat dan bagaimana daerah tersebut mampu memberikan rasa aman bagi pengunjung yang datang. Salah satu tempat wisata yang langsung berinteraksi dengan masyarakat adalah eco tourism yang berada di kampung Genteng Candirejo. Kampung tersebut memberikan fasilitas-fasilitas untuk kenyamanan ditempat tersebut, salah satunya tempat duduk, terdapat kamera pengawas, dan lainnya. Para penduduk juga menyambut dengan baik para pengunjung atau wisatawan yang ingin mengetahui apa saja kegiatan yang dilakukan di kampung tersebut. Salah satu kegiatannya adalah bagaimana cara untuk menanam dan merawat tanaman, terutama tanaman herbal.

Prerequite: Aspek ini digunakan untuk mengukur city branding dari suatu kota berdasarkan bagaimana kualitas suatu kota, apakah di kota tersebut memuaskan, memiliki standar fasilitas umum seperti sekolah, rumah sakit, transportasi, dan fasilitas olahraga. Kota 
Surabaya banyak memiliki fasilitas rumah sakit, salah satunya RSUD Dr. Soetomo, dan lainnya. Dari segi fasilitas transportasi, kota Surabaya memiliki Surabaya bus dengan membayar menggunakan botol plastik, lalu dari segi tempat olahraga kota Surabaya memiliki taman yang menyediakan lapangan tempat bermain sepak bola atau futsal, salah satunya taman apsari, dan sekitar taman bungkul setiap minggu diadakan Car Free Day.

\section{SIMPULAN}

City branding sebagai strategi pengembangan pariwisata lokal yang dilakukan untuk meningkatkan kunjungan wisatawan. Dengan potensi dan keunggulan di bidang pariwisata dan juga pendidikan, Kota Surabaya dapat memiliki identitas yang kuat sebagai kota wisata. Dengan adanya bangunan-bangunan peninggalan Belanda yang tersisa di Surabaya dan juga terdapat banyak sekolah-sekolah negeri maupun swasta yang memiliki fasilitas teknologi yang baik, fasilitas bangunan yang nyaman, fasilitas buku yang menunjang pendidikan, dan lainnya. Maka dari itu, Kota Surabaya memiliki city branding yang bertemakan "Sparkling Surabaya". Penggunaan Sparkling Surabaya adalah cara untuk memperkenalkan kepada masyarakat luas atau wisatawan sehingga dengan adanya Sparkling Surabaya ini sebagai pengikat seluruh komponen dan lapisan masyarakat beserta pemerintah untuk mempromosikan Kota Surabaya sebagai kota wisata. Pemerintah Kota Surabaya sudah memberlakukan strategi yang berguna dalam meningkatkan kunjungan wisatawan, yaitu menggunakan strategi pemasaran (marketing) atau promosi di dalam city branding melalui website, akun instagram, adanya Bus SSCT, dan diadakannya event-event atau kegiatan salah satunya Car Free Day.

\section{DAFTAR PUSTAKA}

Arifin, M. (2017). Strategi Manajemen Perubahan Dalam Meningkatkan Disiplin Di Perguruan Tinggi. Journal of Chemical Information and Modeling, 169), 1689-1699. https://doi.org/10.1017/CB0978110741532 4.004
Ferreira, P., \& Dionísio, A. (2019). City brand: What are the main conditions for territorial performance? Sustainability (Switzerland), 11(14), 1-14. https://doi.org/10.3390/su11143959

Hambalah, F. (2017). Surabaya Sebagai Kota Maritim : Strategi Pemasaran. 20(1), 61-69.

Hidayat, M. R., \& Thamrin. (2019). Analisis Proses City Branding ' Taste Of Padang ' sebagai Brand Destinasi Pariwisata Sumatera Barat. Jurnal Kajian Manajemen Dan Wirausaha, 01, 241-258.

Hilman, Y. A., \& Megantari, K. (2018). Model City Branding Sebagai Strategi Penguatan Pariwisata Lokal Provinsi Jawa Timur. Jurnal Komunikasi Dan Kajian Media, 2(2), 22-35.

Himawan, M. A. D. (2018). Deskripsi Percakapan Kritis Matematis Siswa Dengan Metode Socrates Dalam Pendekatan Saintifik (Penelitian Kualitatif Deskriptif pada Siswa Kelas VII A SMP Negeri 1 Natar Semester Ganjil Tahun Pelajaran 2017/2018). World Development, 1(1), 1-15. https://doi.org/10.1016/j.worlddev.2018.08. 012

https://sparkling.surabaya.go.id/en/. (n.d.).

Intyaswono, S., Yulianto, E., \& Mawardi, M. K. (2016). Peran Strategi City Branding Kota Batu dalam Trend Peningkatan Kunjungan Wisatawan Mancanegara. Jurnal Administrasi Bisnis, 30(1), 65-73. Retrieved from administrasibisnis.studentjournal.ub.ac.id\%0A Lauwrentius, S., Fianto, A. Y. A., \& Yosep, S. P. (2015). Penciptaan City Branding Melalui Maskot Sebagi Upaya Mempromosikan Kabupaten Lumajang. Jurnal Art Nouveau, 4(2), 162-171. Retrieved from https://jurnal.dinamika.ac.id/index.php/ArtN ouveau/article/view/974

Musaddad, A. A., Rahayu, O. Y., Pratama, E., Supraptiningsih, \& Wahyuni, Ev. (2011). Dinamika Administrasi Publik. Jurnal Ilmu Administrasi Dan Manajemen, 2(April).

Nawangsari, E. R., \& Suksmawati, H. (2019). City Branding Policy And Regional Marketing In Indonesia. RJOAS, 6(June), 68-75. https://doi.org/10.18551/rjoas.2019-06.10

Novikova, E., Mityagina, V., Gureeva, A., \& Makhortova, T. (2018). Branding in Urban Discourse Space: Region's Identity as Attraction Factor. SHS Web of Conferences, 50, 01066.

https://doi.org/10.1051/shsconf/201850010 66 
Pantow, V. A. M., \& Fista, B. R. S. (2018). Sikap Warga Putat Jaya Mengenai City Branding Kota Surabaya Melalui Program Revitalisasi Eks Lokalisasi Dolly. Jurnal Komunikatif, 7(1), 126. https://doi.org/10.33508/jk.v7i1.1744

Ramadhan, A. H., Suharyono, \& Kumadji, S. (2015). Pengaruh City Branding Terhadap Minta Berkunjung Serta Dampaknya Pada Keputusan Berkunjung (Survei pada Wisatawan Kota Surabaya 2015). Jurnal Administrasi Bisnis, 28(2), 1-7.

Romli, R., \& Romli, N. A. (2020). Implementasi strategi komunikasi "Bandung Juara" sebagai bagian dari city branding Kota Bandung.
PRofesi Humas Jurnal Ilmiah Ilmu Hubungan Masyarakat, $4(2)$, 263. https://doi.org/10.24198/prh.v4i2.23547

Setiyaningrum, A., Udaya, J., \& Effendi. (2015). Prinsip - Prinsip Pemasaran (1st ed.; Maya, Ed.). Yogyakarta: ANDI.

Soewadji, J. (2012). Pengantar Metodologi Penelitian. Mitra Wacana Media.

Undang - Undang Republik Indonesia No. 9 Tahun 1990 Tentang Kepariwisataan.

Wibowo, T. O. (2018). Strategi Pengembangan Daya Tarik Kota Lasem Sebagai Kota Batik-Kopi. Jurnal Pariwisata Terapan, 2(1), 1. https://doi.org/10.22146/jpt.35371 